\title{
RESEARCH ON AND PRACTICE OF ADDITIVE MANUFACTURING TECHNOLOGIES
}

\author{
PÉTER FICZERE*1 \\ ${ }^{1}$ Department of Railway Vehicles and Vehicle System Analysis, Budapest University of Technology and \\ Economics, Múegyetem rkp. 3, Budapest, 1111, HUNGARY
}

\begin{abstract}
Today, additive manufacturing technologies are becoming increasingly popular. In order to take advantage of the opportunities offered by these new technologies, a different way of thinking at the design stage needs to be adopted. This new design thinking must be introduced into engineering education. In order to achieve this at the right level, practical experience is needed in parallel with a theoretical background on the technologies. This paper provides a brief overview of my research and results in the field of additive manufacturing.
\end{abstract}

Keywords: additive manufacturing, 3D printing, generative design, fused deposition modeling, material properties

\section{Introduction}

The spread of additive manufacturing technologies continues unabated. More and more applications are becoming commonplace. However, in certain areas, they must be applied cautiously. In many areas, questions are raised about which materials and technology to use from health, mechanical and strength points of view. Similarly, whether it is economically worthwhile to use this manufacturing process if other methods can be implemented to produce the part is a matter of debate.

Since the process is becoming more and more prevalent in industry, its inclusion in higher technical education is necessary. However, practical experience is also needed to ensure an adequate level of education. Another benefit of introducing additive manufacturing technologies into education is that it is a novel, interesting and exciting field that attracts the interest of students, which in turn boosts research in this area.

My research on additive manufacturing technologies began at the Department of Railway Vehicles and Vehicle System Analysis - formerly known as the Department of Vehicle Elements and Vehicle System Analysis (DRVVSA) at the Budapest University of Technology and Economics (BUTE) in 2007 through my PhD research. At that time, my research was supported by VARINEX Zrt. who produced test specimens for the investigations.

In 2015, the department also acquired two Fused Deposition Modeling (FDM) 3D printers, increasing the number of opportunities and expanding the spectrum of

\footnotetext{
*Correspondence: ficzere.peter@kjk.bme.hu
}

my research. By this time, my investigations mainly focused on handmade pieces.

A significant proportion of the required measurements was carried out at the Department of Polymer Engineering and in the research laboratories at the Biomechanical Cooperative Research Centre both at the BUTE.

The results of my research are presented in this paper.

\section{Method}

A significant amount of experimentation is necessary to properly understand production technologies. During these experiments, questions often arise as to whether this or that can be achieved with this or that technology. Therefore, the fields of application were extended and the printers made available to students, which led to even more interesting and often questionable outcomes.

As the printers purchased (Prusa i3 and Zortrax M200) are open-source, the production parameters could be set as desired and the effects of each setting tested.

Another important and continuously explored as well as developed area is the investigation into the applicability of the technology.

\section{Results}

\subsection{Accuracy tests}

Specimens of different shapes and geometries were produced to determine the accuracy of the machine and the surface quality of the printed parts.

Unfortunately, the studies did not provide precise and clear figures [1] since their accuracy is affected by 
- the geometry of the part to be printed (flat or curved surfaces, curvature rate, position of the planes (horizontal, vertical or inclined));

- tolerances of conversion from the original CAD geometry to the STL file (input for the printer)

- the layer thickness

- the printing speed

- the printing temperature

- heating the table

- the orientation

- different levels of accuracy in the $x-y$ (layer) plane and perpendicular ( $z$-direction) to it

Of course, these variables refer to printing using the same machine and different values may be obtained should another machine of an alternative type be applied.

It is important to note that some errors due to the manufacturing principle can be eliminated by preliminary modifications of the CAD model (toolpath correction), but some more advanced CAM software (code generators) are already capable of doing this.

The size correction needed to connect parts in operating assemblies was also investigated.

\subsection{Fields of application}

Due to a lack of space, only some of the completed projects are presented here, but many other smaller objects were printed, e.g., parts for robotic cars for the Bosch Future Mobility Challenge, miniature copies of traffic signs for sign-recognition simulations (for the Department of Automotive Technologies at the BUTE), various sprockets, battery holders, unique pieces of "jewellery", ornaments, parts, representation and marketing materials, utility items, educational aids, etc.

\section{Supply of spare parts}

In many cases, given that it is not possible to obtain spare parts for a component that has failed in an older device, a copy of the component in question must be manufactured, otherwise the device becomes inoperable and therefore worthless. Although this technology is particularly important for veteran vehicles, in this case special attention must be paid to the stresses and strains on the components produced by the new method, moreover, should the part produced be non-compliant, it could even damage other irreplaceable parts [2].

Several individual parts that seemed to be irreplaceable have also been redesigned and manufactured (Fig. 1).

Nowadays, it is also important to note that more and more people are considering this solution to the lack of spare parts, purely for economic reasons. In the case of a major automotive unit or structure, the supply of spare
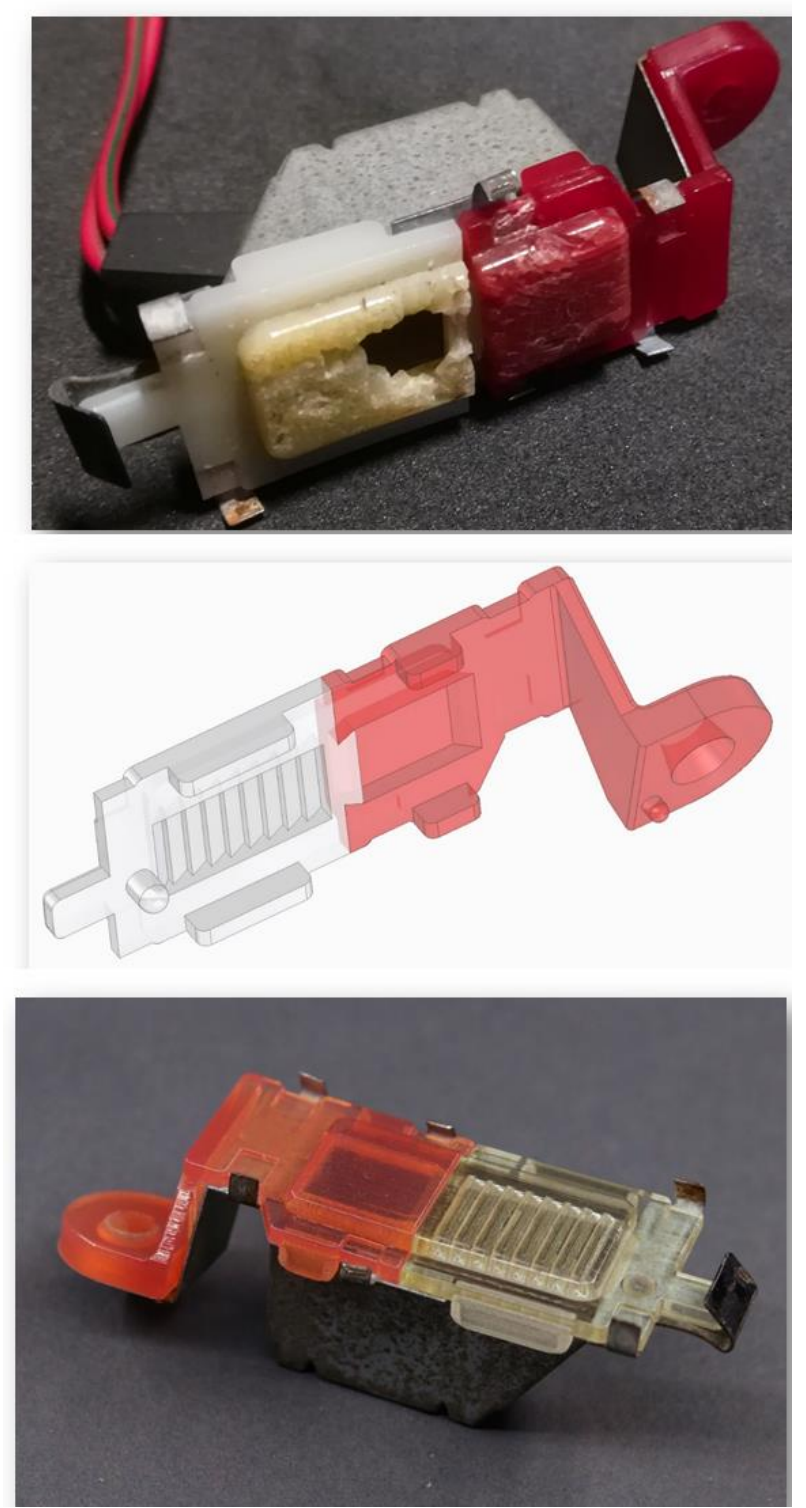

Figure 1: Replacement of individual parts [2]

parts has to be ensured even decades after its production has stopped. It is of course impossible to determine in advance exactly how many parts will need to be replaced. For this reason, manufacturers often accumulate unreasonably large stocks of specific parts, which are extremely costly to store or the machines and tools that produce them are costly to maintain.

\section{Prototype development}

Several prototypes have been developed at our department. One of the most interesting of which was the development of a medicine capsule. As is well known, the action of so-called retard capsules (composed of soft gelatine that is dissolved by acidic conditions found in the human stomach) is delayed. This delay and the extent of its effect also depend on the individual, making it difficult for the optimal dose of the active ingredient to be 


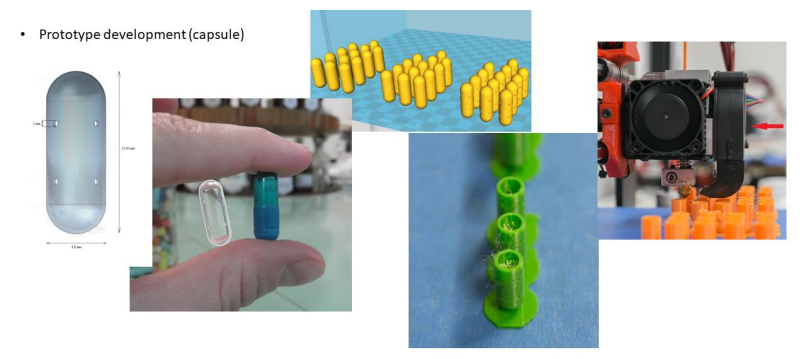

Figure 2: Prototype development (capsule) [3]
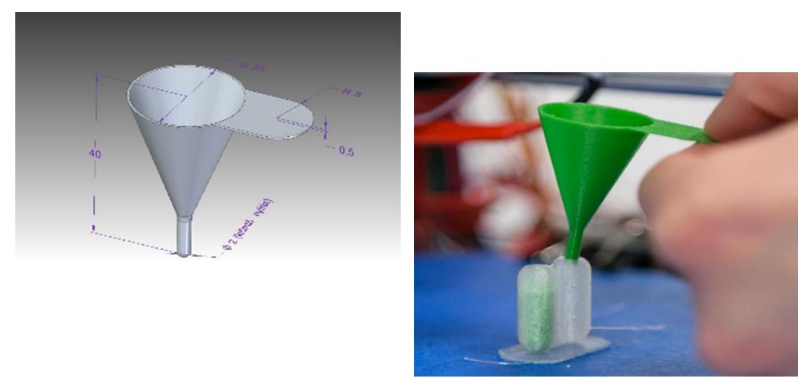

Figure 3: The manufacture of assistive devices [3]

determined correctly. The basic idea was to produce capsules of the same size as the original capsules, with various numbers of holes of different dimensions and shapes. The effect of such modifications on the rate and extent of release was then investigated. For the purposes of the studies, the individually designed capsules were printed and filled with a given quantity of caffeine pellets (Figs. 2 and 3) $[3,4]$.

It can easily be seen that designing a modified mould for a part produced in large quantities by injection moulding before stopping production and changing the mould for a few parts needed for testing is not a cost-effective solution, which can lead to a serious loss of revenue [5].

In the same case, in order to fill the miniscule and lightweight caffeine pellets (it was particularly difficult to fill the capsules with the amount measured out into small sachets to the nearest microgram), a small funnel was designed and printed within a few minutes.

\section{Making tools and moulds}

In many cases, high demands for the material the parts are composed of may be infeasible by applying some additive manufacturing technologies. In a case study when individual castings have to be produced, a casting mould for the remanufacture of a cylinder from the engine of a veteran vehicle can be seen in the middle photo of Fig. 4. On the left-hand side of the figure, a 3D CAD model is shown, which was used to print the mould from acrylonitrile butadiene styrene (ABS) using an FDM printer to produce (and later functionally assemble) the casting (right-hand side of Fig. 4) [6].

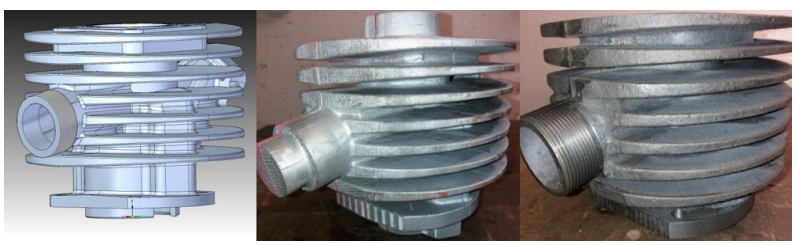

Figure 4: CAD model, 3D-printed casting mould and casted cylinder [6]

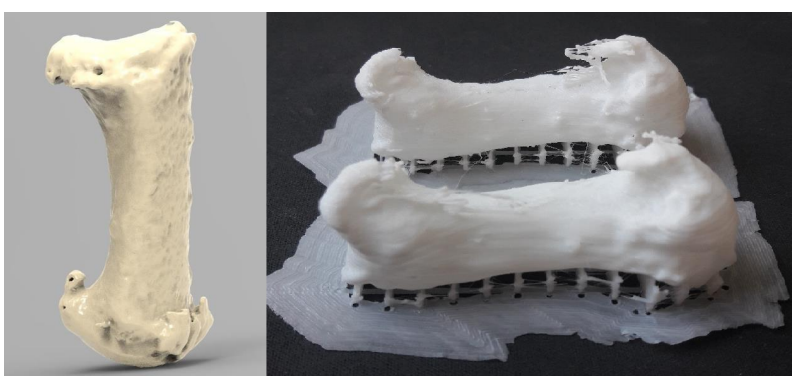

Figure 5: CAD model of a human metacarpal remodeled from CT scans and the printed pieces [8]

\section{The manufacture of medical implants and devices}

One of the areas where additive manufacturing is expected to make the greatest amount of progress is the rapid and customizable production of medical implants and devices. Since the geometry of a given implant has to perfectly match the intact body parts of the person, very stringent requirements must be met with regard to the formal design (shape) of the model $[7,8]$.

However, these pieces also need to match the stiffness of a person's individual bone in terms of mechanical strength. The department has carried out several research projects along these lines.

In the case of the human metacarpal shown in Fig. 5 and 6, the geometry had to be modelled from CT scans. The stiffness of the real bone was measured, then the geometry of the 3D CAD assigned to the model with the 3D-printed material properties and the internal geometry changed by shape optimization until the stiffness of the printed piece perfectly matched the stiffness of the original bone.

\section{Optical photostress investigations}

Since it is also possible to print from transparent (translucent) materials, the coating required for optical photostress investigations (which is difficult and timeconsuming for complex geometries) can be easily printed given the right thickness and quality, thereby saving much time and reducing the amount of effort required (Fig. 7) $[9,10]$.

An additional advantage of this method is that it allows us to detect and determine the residual stresses that develop during production (Fig. 8) [11]. 

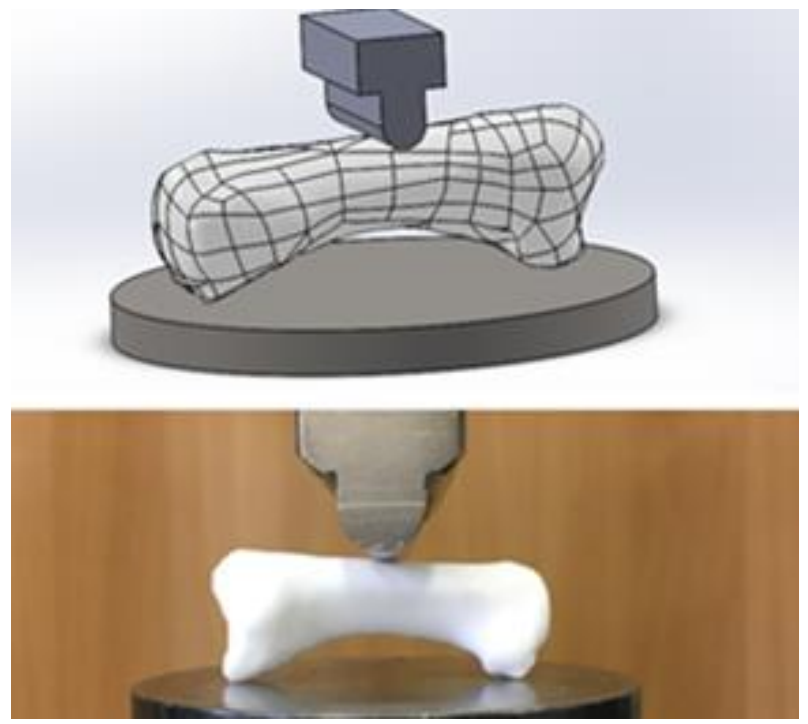

Figure 6: Validation of the material model used by the numerical simulation of a human metacarpal with measurements on a real printed part [7]

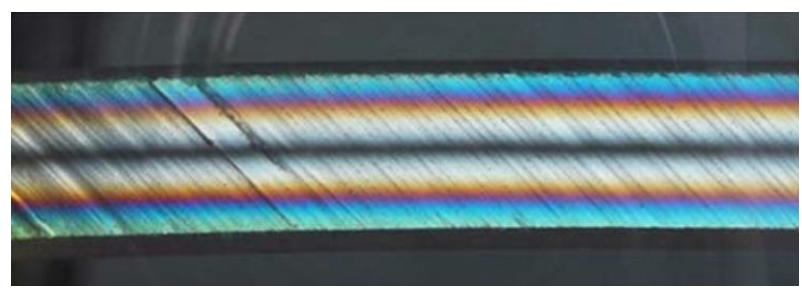

Figure 7: Fringe pattern on a 3D printed test specimen as a result of bending [9]

\subsection{Economic analysis}

When printing individual parts, how manufacturing costs are affected by the production of the workpiece quickly becomes apparent.

- chosen procedure

- production time, the 3D printing speed

- placement on the workspace

- position, orientation

- the quantitative requirement for support materials

- type of support materials

- percentage of filling

- type of filling

- layer thickness

- choice of materials

- number of units to be produced

Several economic calculations have been made to identify areas where the technology offers real advantages over other manufacturing processes [12].

How the aforementioned parameters affect production costs either directly or indirectly has also been investigated $[5,13]$.

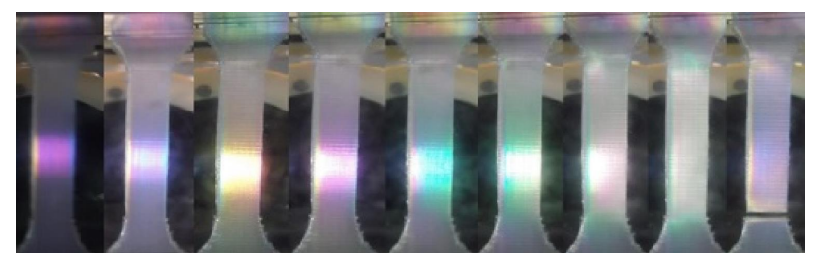

Figure 8: Residual stresses in specimens subjected to tensile testing [11]

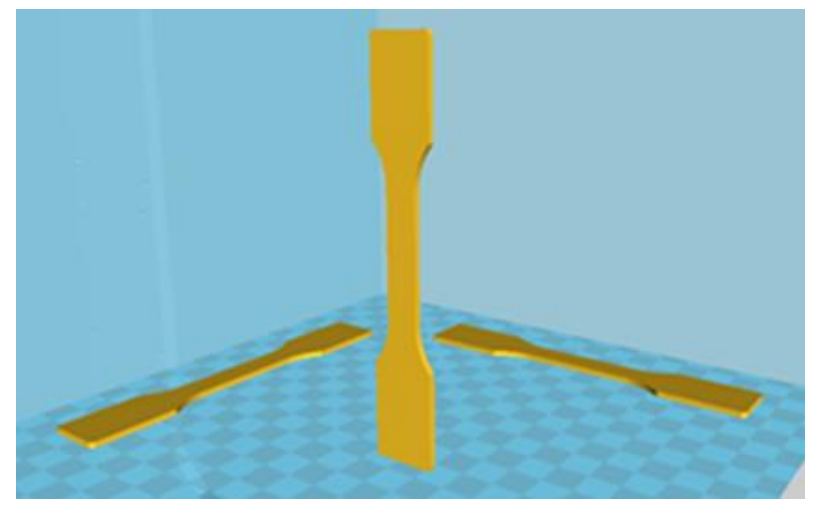

Figure 9: Test specimens produced in different directions and positions [14]

\subsection{Material investigations}

Additive manufacturing technologies are characterized by the fact that they compose arbitrarily complex parts, even with hollow geometries inside, layer by layer [14]. This implies that the bonding of layers to each other is assumed to be different from the bond strength within the layers [15], which has been proven in several cases.

In several manufacturing processes of different materials, how the material properties (of lying and standing specimens) in different directions relate to each other has been investigated (Fig. 9). The tensile curves in the highlighted directions were measured:

- FullCure 720 produced by the PolyJet process [1]

- FDM process and polylactic acid (PLA) [16]

- FDM process and Acrylonitrile Butadiene Styrene (ABS) [17]

- Selective Laser Sintering (SLS) process and polyamide 12 (PA12) [18]

- FDM process and Soft PLA (flexible plastic) [19]

- FDM process and High Temperature (HT) PLA (thermosetting plastic) [20]

Apart from the SLS process, the results show that the behavior of additively manufactured parts can be described by the model of an orthotropic material under all circumstances. Therefore, the determination of the corresponding material properties is a more complex task [21], where it is insufficient to only use Young's modulus E and Poisson's ratio $\nu$ to describe the behavior of a material. In addition, the shear modulus of elasticity $G$ must be measured [22]. 


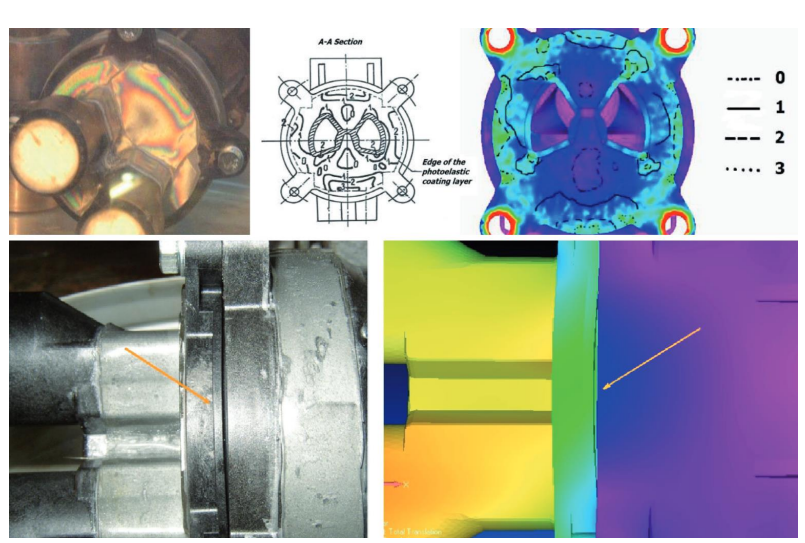

Figure 10: Validation of a material model by the optical photostress method [25]
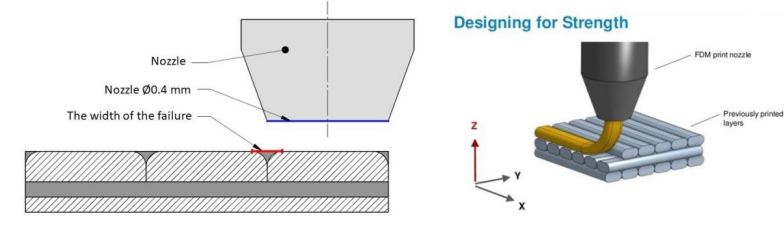

Figure 11: Identifying the causes of errors [25]

Of course, after determining the material models and material properties using a tensile testing machine, the results need to be validated. For this purpose, a method has been developed [23].

The effects of certain manufacturing parameters on strength have also been determined [24] and the reasons for these explored (Figs. 10 and 11) [25].

\section{Dynamic materials testing}

As certain components are also subject to dynamic loads, it is necessary to examine the parts manufactured by these processes for dynamic stresses. This test method has also been developed and performed on parts composed of PLA manufactured by FDM (Fig. 12) [26].

\section{Modification options affecting material properties}

Several options have been investigated that influence the mechanical strength parameters, including active cooling [27], the effect of heat treatment (publication in progress) and ironing (publication in progress).

\subsection{Examination of the impact of infill}

The possibilities of producing parts subjected to quasiuniform stresses in a way that reduces the cumbersome and lengthy post-processing operations were also investigated. Such a method is the modification of the internal filling according to the stresses [28].

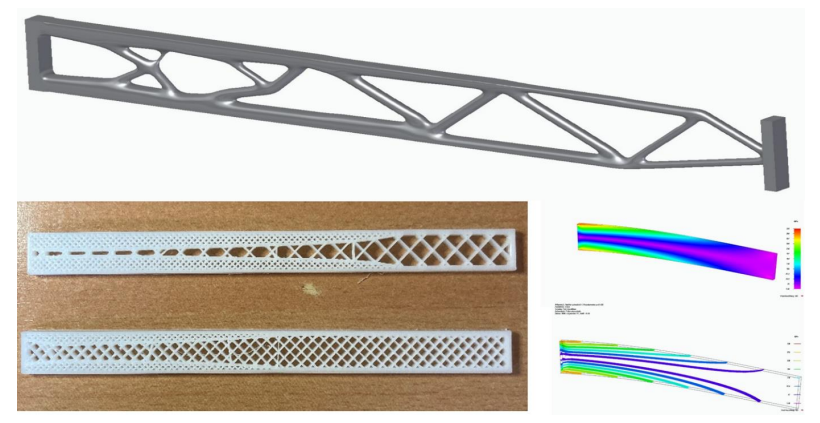

Figure 12: Difficult and easy to manufacture uniform strength supports [28]
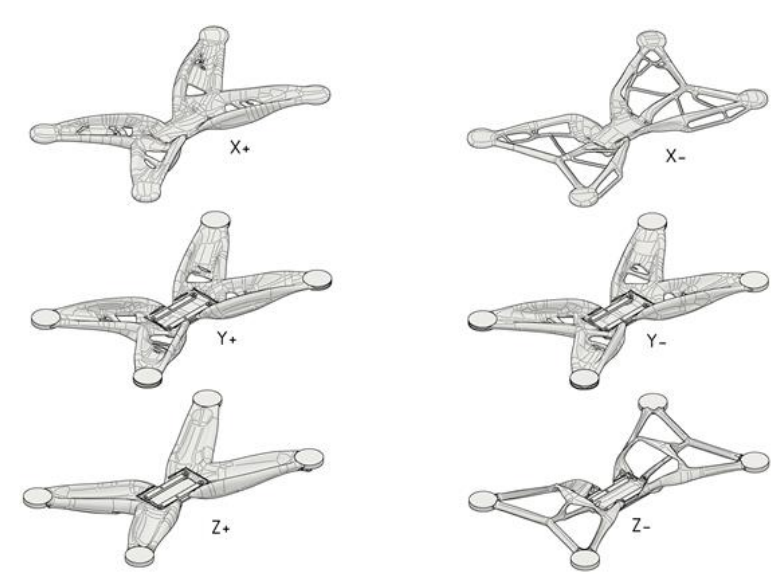

Figure 13: Drone to be manufactured by 3D printing using generative design

\subsection{Generative design in terms of additive manufacturing technologies}

Artificial intelligence-based design methods that can be used to design geometries according to different criteria, which by and large can only be produced by additive manufacturing, are currently being investigated (Fig. 13).

\section{Acknowledgments}

The author would like to express their gratitude to György Falk (VARINEX Zrt.) who greatly helped with the research in terms of both printing and giving professional advice.

The author is grateful to Dr. László Lovas who, as the head of the department, recognized the research potential of $3 \mathrm{D}$ printing and purchased the printers for the department as well as the necessary materials.

Last but not least, the author would like to thank Dr. Gábor Szebényi who provided the material investigations.

\section{REFERENCES}

[1] Ficzere, P.; Borbás, L.; Török, Á.: Theoretical and practical investigation of rapid prototyping, in: Borkowski, S.; Selejdak, J.; Jelacič, D.; Hadzima, B. (Eds.) Toyotarity. Standarizations' Kinds, 
pp. 139-150 (Yurii V. Makovetsky, Dnipropetrovsk, Ukrayne) 2011 ISBN: 978-966-1507-77-6

[2] Janoch, Á.; Ficzere, P.: Additív gyártástechnológiák szerepe a veterán gépjármúvek alkatrészellátásában, GÉP, 2019, 70(3), 38-41 http://epa.niif.hu

[3] Horváth, Á.M.; Ficzere, P.: Rapid prototyping in medical sciences. Prod. Eng. Arch. 2015, 8(3), 2831 DOI: 10.30657/pea.2015.08.07

[4] Ficzere, P.; Horváth, Á. M.; Sipos, T.: Elalvásos balesetek csökkentési lehetôsége additív gyártási eljátrással fejlesztett kapszulák segítségével. Közlekedéstudományi Szemle, 2020, 70(1), 77-85 DOI: 10.24228/KTSZ.2020.1.3

[5] Ficzere, P.; Borbás, L.; Török, Á.: Economical investigation of rapid prototyping. Int. J. Traffic Transp. Eng., 2013, 3(3), 344-350 DOI: 10.7708/ijtte.2013.3(3).09

[6] Lovas, L.: Öntőforma készítés 3D nyomtatással. GÉP, 2016, 67(7-8), 13-16

[7] Ficzere, P.: Design questions of the individual medical implants, in: Haber, I.; Bogdan, Cs.; Szoke, A. (Eds.) Proceedings of 4th international interdisciplinary 3D conference: Engineering section, pp. 5767 (University of Pécs, Pécs, Hungary), 2018 ISBN: 978-963-429-267-8

[8] Ficzere, P.; Bogya, P.; Horváth, E.; Lovas, L.: Simplified cad model of human metacarpal for implantation. Des. Mach. Struct., 2018, 8(2), 5-12 https://www.uni-miskolc.hu

[9] Ficzere, P.: Usage of 3D printing in photostress investigation. Prod. Eng. Arch. 2015, 7(2), 16-19 DOI: 10.30657/pea.2015.07.04

[10] Ficzere, P.; Borbás, L.: New application of 3D printing method for photostress investigation. Mater. Today: Proc. 2016, 3(4), 969-972 DOI: 10.1016/j.matpr.2016.03.030

[11] Ficzere, P.; Borbás, L.; Szebenyi, G.: Reduction possibility of residual stresses from additive manufacturing by photostress method. Mater. Today: Proc. 2017, 4(5), 5797-5802 DOI: 10.1016/j.matpr.2017.06.048

[12] Seregi, B.L.; Ficzere, P.; Borbás, L.: Fémalkatrészek additív és szubtraktív módon történő gyártásának összehasonlítása. Acta Periodica, 2021, 22, 18-32 DOI: 10.47273/AP.2021.22.18-32

[13] Ficzere, P.: Effect of 3D printing direction on manufacturing costs of automotive parts. Int. J. Traffic Transp. Eng. 2021, 11(1), 94-101 DOI: 10.7708/ijtte.2021.11(1).05

[14] Győri, M.; Ficzere, P.: Use of sections in the engineering practice. Period. Polytech. Transp. Eng. 2017, 45(1), 21-24 DOI: 10.3311/PPtr.9144

[15] Ficzere, P.; Borbás, L.: Material law for numerical analysis of rapid prototype products, in: Cosmi, F.; Iacoviello, F.; (Eds.) Proceedings of the 9th Youth Symposium on Experimental Solid Mechanics, Trieste, Italy, July 7-9, 2010, pp. 120-122 (Gruppo Italiano Frattura, Italy) ISBN: 978-88-95940-30-4
[16] Ficzere, P.; Borbás, L.; Falk, Gy.: Additív gyártástechnológiák alkalmazhatósági vizsgálata testreszabott orvosi implantátumok méretezéséhez. Biomech. Hung. 2018, 11(2), 69-75 DOI: 10.17489/2018/2/10

[17] Markiz, N.; Horváth, E.; Ficzere, P.: Influence of printing direction on 3D printed ABS specimens. Prod. Eng. Arch. 2020, 26(3), 127-130 DOI: 10.30657/pea.2020.26.24

[18] Ficzere, P.; Borbás, L.; Falk, Gy.; Szebenyi, G.: Experimental determination of material model of machine parts produced by Selective laser sintering (SLS) technology. Mater. Today: Proc. 2018, 5(13), 26489-26494 DOI: 10.1016/j.matpr.2018.08.104

[19] Kis, K.; Ficzere, P.; Kovács, N.K.; Szebényi, G.: Additív gyártástechnológiával előállítható rugalmas múanyagok vizsgálata. GÉP, 2018, LXIX: 4, 49-53 http://epa.niif.hu

[20] Lukács, N.; Ficzere, P.; Szebényi, G.: The impact of active cooling on heat resistant PLA. Müszaki Tudományos Közlemények (EN), 2020, 13(1), 118 121 DOI: 10.33894/mtk-2020.13.21

[21] Ficzere, P.; Borbás, L.: Method to reduce the independent constants of orthotrop materials in rapid prototyping, in: Proceedings of the 11th Youth Symposium on Experimental Solid Mechanics, Brașov, Romania, May 30-June 2, 2012 pp. 129-135 (Curran Associates, Inc., Red Hook, NY, USA) ISBN: $978-$ 1-63439-432-1

[22] Ficzere, P.; Borbás, L.: Experimental investigation of the shear modulus in the case of pure tensile test. Trans. Famena, 2018, 42(1), 27-36 DOI: 10.21278/TOF.42103

[23] Ficzere, P.; Borbás, L.; Török, Á: Validation of numerically simulated rapid-prototype model by photoelastic coating. Acta Mech. Slovaca, 2014, 18(1), 14-24 DOI: 10.21496/ams.2014.002

[24] Ficzere, P.; Lukács, N.L.: Influence of 3D printing parameters. IOP Conf. Ser.: Mater. Sci. Eng. 2020, 903, 012008 DOI: 10.1088/1757-899X/903/1/012008

[25] Ficzere, P.; Lukács, N.L.; Borbás, L.: The investigation of interlaminar failures caused by production parameters in case of additive manufactured polymers. Polymers, 2021, 13(4), 556 DOI: 10.3390/polym 13040556

[26] Ficzere, P.: Experimental dynamical analysis and numerical simulation of the material properties of parts made by fused deposition modelling technologies. Period. Polytech. Transp. Eng. 2020, 48(3), 221-225 DOI: 10.3311/PPtr.13947

[27] Ficzere, P.; Lukács, N.L.: The influence of active cooling on heat resistant PLA in FDM technologies. Mach. Des. 2020, 12(2), 37-40 http://www.mdesign.ftn.uns.ac.rs

[28] Ficzere, P.; Lukács, N.L.: Examination of possibilities of the strength modification in the case of FDM/FFF manufacturing technology. Des. Mach. Struct. 2020, 10(2), 27-34 https://www.uni-miskolc.hu 